Nigerian Journal of Environmental Sciences and Technology (NIJEST)

www.nijest.com

ISSN (Print): 2734-259X | ISSN (electronic): 2734-2603

Vol 4, No. 2 October 2020, pp 351 - 369

\title{
The Thickening Time of Ferrous Cement Slurry System in High- Pressure and High-Temperature Environment
}

\author{
Igbani S. ${ }^{1} *$, Ogoni H. A. ${ }^{2}$ and Appah D. ${ }^{3}$ \\ ${ }^{1}$ Department of Petroleum Engineering, Faculty of Engineering, Niger Delta University, Nigeria \\ ${ }^{2}$ Department of Chemical Engineering, Faculty of Engineering, Niger Delta University, Nigeria \\ ${ }^{3}$ Department of Petroleum Engineering, Faculty of Engineering, University of Port-Harcourt, Nigeria \\ Corresponding Author:*sundayigbani@gmail.com
}

https://doi.org/10.36263/nijest.2020.02.0219

\begin{abstract}
Experimentally, the aim of this research paper is to investigate the thickening time (TT) of different ferrous cement slurry systems in high-pressure and high-temperature (HPHT) environment. Objectively, the study collected eight (8) samples of groundwater from 8 different boreholes, as mix-water, from the study area, Kolo Creek. These mix-water samples were subjected to water chemistry analysis, based on the American Public Health Association (APHA) drinking water test methods; the results obtained from these tests were benchmarked with the standard values of World Health Organisation (WHO), and Nigeria Standard Drinking Water Quality (NSDWQ) standards. These results reveal that, in each of the tested mix-water samples, ferrous ion $\left(\mathrm{Fe}^{2+}\right)$ concentration was higher $(0.52$ to $6.82 \mathrm{mg} / \mathrm{L})$; which is greater than $0.3 \mathrm{mg} / \mathrm{L}$, and this was the only chemical parameter that was in strong disagreement with the WHO's and NSDWQ's Drinking Water Quality standards. Subsequently, each of these ferrous mix-waters were used in the formulation of cement slurries at the water-to-cement ratio of 0.44 in batches; each of these formulated slurries were used, to test for the effects offerrous ion concentration in mix-water on the TT performances of the slurries. These TT tests were performed using the Chandler model 7322 HPHT Consistometer. These tests were conducted based on the API Specification 10A methods of 1995. Generally, the results obtained reveal that, as the concentration of $\mathrm{Fe}^{2+}$ increases in the mix-water, the TT of the cement slurry accelerated in the HPHT environment. This means that the cement slurry set faster. Also, this set-fast behaviour of high ferrous ion concentration towards slurry suggested that, high concentration offerrous ion induced the exothermic reaction of tricalciumaluminate $\left(C_{3} A\right)$ during the hydration of the ferrous cement slurry. Therefore, ferrous neat cement slurry is only suitable for cementing shallow oil-well, except retarding additives are added into the slurry.
\end{abstract}

Keywords: Thickening Time, Mix-Water, Oil-well Cement, Ferrous Ion, Cement Slurry, HighPressure, and High-Temperature

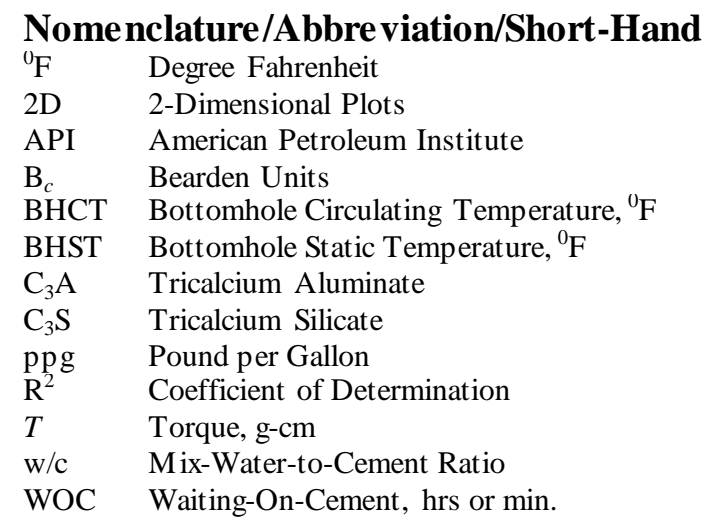

$\begin{array}{ll}\mathrm{Fe}^{2+} & \text { Ferrous ion Concentration, mg/L } \\ \mathrm{HPHT} & \text { High-Pressure }(\mathrm{psi}) \text { and High-Temperature }\left({ }^{0} \mathrm{~F}\right) \\ \mathrm{M} & \text { Molarity } \\ \mathrm{Mg} / \mathrm{L} & \text { Milligram per Litre } \\ \mathrm{Min} & \text { Minutes } \\ \mathrm{Na}_{2} \mathrm{SiO}_{3} & \text { Sodium Silicate } \\ \mathrm{NaOH} & \text { Sodium Hydroxide } \\ \mathrm{OWC} & \text { Oil-well Cement } \\ \mathrm{Psi} & \text { Pounce per Second Inch } \\ \mathrm{t} & \text { Time, hrs or min } \\ \mathrm{TT} & \text { Thickening Time } \\ \text { WHO } & \text { World Health Organisation }\end{array}$

\subsection{Introduction}

The thickening time (TT) of cement slurry is a measurement of the time during which oil-well cement (OWC) slurry remains in a pumpable non-Newtonian fluid state (Roshan and Asef, 2010). The 
pumpable state is usually between 20 minutes to days, at prevailing oil-well in situ conditions (Alp and Akin, 2013; Salam et al., 2013). In addition, Salam et al. (2013) explained that, this pumpable time includes the time spent in mixing the powdered cement, mix-water, and additive(s) in a cement mixer; and the time after initial mixing up to the time, when the cement can no longer be pumped. Explicitly, this means that the TT is the sum-up periods of mixing the cement slurry, pumping, displacement of drilling mud, placement of cement slurry at the desired subsurface location in the wellbore, and release of inflatable plug, including the safety factor of 1 to 2 hours (Dillenbeck, 2010). Nevertheless, this process depends on the downhole temperature and pressure profile, the mixing of the powdered cement, quantity and quality of mix-water, the ground particle size of the powdered cement, and the additives used (Boniface and Appah, 2014); thus TT can be evaluated up to the pressure, and temperature of 30,000 psi, and $400{ }^{\circ} \mathrm{F}$ in most ultra-HPHT reservoir, respectively; using a device known as pressurized consistometer (API Specification 10A, 1995; DeBruijn, 2008; BroniBediako et al., 2015). During TT tests in the HPHT consistometer, as the cement slurry begins to set, the points of departure is observed from the potentiometer. These points of departure are the points with respect-to-time, at which the consistency or apparent viscosity, of the cement slurry begins to increase. These points are very crystal clear at 30, 70, and 100 Bearden Units $\left(B_{c}\right)$. Although, in most cases, the final departure point of $100 \mathrm{~B}_{\mathrm{c}}$ is the consistency, at which the slurry seized, to be pumpable; but, in some studies $70 \mathrm{~B}_{\mathrm{c}}$ is considered, to indicate the maximum consistency for the slurry, to still be in a non-Newtonian pumpable state (Dargaud and Boukhelifa, 2006; Broni-Bediako et al., 2015).

Despite the aforementioned tests, it should be noted that the pressurised fortified metallic vessel used to hold the sampled cement slurry into the consistometer, does not simulate or represent real oil-well downhole prevailing conditions; mostly the reservoir formation characteristics (Bourgoyne et al., 1986). Since, in actual well conditions, mix-water used to prepare cement slurry can infiltrate into a permeable formation, fractured or dual fractured formation, through the challenging processes of fluid filtration, lost circulation, and fluid loss (Igbani et al., 2018). Hence, the estimated wellbore real TT may be probably less or greater than, what is been predicted during the laboratory slurry design (Azar and Samuel, 2007). Furthermore, the measuring of TT, as determined in a HPHT consistometer, is only related to the torque being placed on a stationary paddle within the rotating slurry metallic cup. Also, the torque does not represent, the impeding factors in the wellbore, militating against the rheological behaviour of the cement slurry. Thus, as the cement sets, the torque increases on the spring-loaded potentiometer connected to the paddle shaft. This torque is recorded as a Direct Current (DC) voltage across a resistor on top of the potentiometer. The actual viscosity of the OWC can then be derived from a linear plot of DC volts versus viscosity in $B_{c}$. In the HPHT consistometer, a torque is applied to a spring-loaded paddle to the cement slurry in the rotating $150 \mathrm{rpm}$ (revolution per minute) slurry cup, in which the $150 \mathrm{rpm}$ represents the pump rate (Saleh et al., 2018). The TT of most cement slurries become "unpumpable" from the range of 40 to $100 \mathrm{~B}_{\mathrm{c}}$ for most oil-well applications; while other API standard for cement slurry TT elapses at $100 \mathrm{~B}_{\mathrm{c}}$ (Van Kleef and Van Vliet, 1993; Purvis et al., 1993; API Specification 10A, 1995).

Consequently, the TT of a cement slurry under real conditions must be ascertained, to ensure sufficient pumping time for the cement slurry to displace the drilling mud, and to properly place the cement slurry at the desired subsurface location. However, excessive or protracted TT must be avoided, to prevent unnecessary rig downtime, settling and separation of cement slurry components; mostly, in a directional or deviated zone of the casing string, nucleation and growth of free-water pockets, and formation of high porosity and channels in cement sheath due to loss of hydrostatic head, and gas cutting. In other words, in a poor designed cement slurry, an unnecessary protracted TT will result in delays of cement slurry set, which comprises higher rig costs, while an unnecessary shorten TT will result in the failure of the cement, to reach its required desired or targeted subsurface depth (Kanesan et al., 2018). Hence, these explained that there are factors that affect the TT of cement slurries. These factors can increase the time for waiting on cement (WOC) of slurry to set, which may prolong the rig downtime - 'retarding cement slurry TT'. On the other hand, some of these factors may shorten the WOC time for cement slurry to set, and this may cause the cement slurry to set prematurely, to exhibit flash set, or set probably at the wrong depth in the wellbore - 'accelerating cement slurry TT' (Azar and Samuel, 2007). Additionally, available study confirmed that, some major factors that affect the TT of cement slurry are the downhole temperature and pressure, improper use of additives, and impurities in mix-water (Pattinasarany and Irawan, 2012). 
Technically, during primary cementing of the annular space, the temperature encountered by the cement slurry, is comprised of the transmitted heat from the bottomhole circulating temperature (BHCT) and the bottomhole static temperature (BHST), including the inherited exothermic heat generated from the cement slurry hydration reaction (Kabinoff et al., 1992; Kutasov and Kagan, 2002; Hole, 2008). Accordingly, as this combined temperatures increases, the TT of cement slurry system gets shorten. This will obviously decrease the WOC time to set, which directly reduces the rig downtime. On this backdrop, Bett (2010) in a report on geothermal oil-well cementing, materials and placement techniques concluded that, BHCT is very critical in the design of OWC slurry, and accurate estimate is necessary, as it affects the slurry TT and rheology. Furthermore, in a recent study, Soltanian and Mortazavi (2016) studied the difficulties that frequently happen, in cementing a low temperature formation with a long setting time, in which the cement is subjective by low temperatures, at which the TT increases. To solve this problem, Soltanian and Mortazavi (2016) formulated a unique cement system, which contained Nano-silica, hollow spherical material, and Class G oil-well cement, and some additives such as dispersants, and fluid loss control agents were used in the cement system. The laboratory tests showed that, the slurry had a low density, excellent fluid loss control, no free fluid, right-angle-set, and a short TT (47 minutes) at low temperatures. Therefore, it is important that a temperature gradient profile be computed, to give the temperature disclosure that the cement slurry will encounter during the pumping operations. Apart from the effect of temperature on cement slurry TT, the bottomhole pressure also affects the TT behaviour of cement slurry. The intended bottomhole flowing pressures of the formation fluids in an oil-well have the tendency to accelerate the TT of a cement slurry. However, the effect of pressure is not practically so pronounced compared to that of temperature. Although, testing a designed cement slurry property in the laboratory requires both simulated downhole pressure and temperature. Accordingly, in another study, an increased pressure on cement slurry was observed to only change the rate of hydration of $\mathrm{C}_{3} \mathrm{~S}$, but did not alter the structure of the cement slurry (Bresson et al., 2002). Besides, the effects of temperature and pressure on the TT of OWC slurry, it has also been reported that density control activities on cement slurry, is another threatening factor on TT.

As a result, in a recent study, Kanesan et al. (2018) investigated the TT of Class F fly ash geopolymer cement for oil-well cementing. In the study, Kanesan et al. (2018) formulated fly ash geopolymer cement slurry, to investigate the role of density and retarder on TT. With regards to this, the reagents used for the cement formulation were class $\mathrm{F}$ fly ash, mix-water, $\mathrm{NaOH}, \mathrm{Na}_{2} \mathrm{SiO}_{3}$, dispersant, and retarder. In addition, the mixing ratio of $\mathrm{Na}_{2} \mathrm{SiO}_{3}$ and $\mathrm{NaOH}$, and the molarity of $\mathrm{NaOH}$ were 0.25 and $8 \mathrm{M}$, respectively. In course of this, three (3) types of samples were prepared and termed as low, medium, and high density mixtures of geopolymer based cement. For the low density mix, mix-water was continuously added into the mix until the optimum and desired density was achieved, but exclusive to the water added to dissolve and dilute $\mathrm{NaOH}$ pellets to obtain the molarity of $8 \mathrm{M}$. But, barite was added into the high density mixtures, to increase the density of the mixtures to the desired slurry density. The required density for a particular slurry mixture was achieved from the manipulation of the quantity of three variables. These variables were fly ash, water, and barite. Water was used to reduce the density of the cement slurry, while barite was used as a heavyweight agent to increase the density of the mixture. After the cement slurries have been prepared, Kanesan et al. (2018) employed the API standards experimental methods, and subjected the slurries to density, and TT tests using the pressurized mud balance, and HPHT Consistometer equipment, respectively; as also enshrined in the API Specification 10A (API Specification 10A, 1995). However, in Kanesan et al. (2018) study, the HPHT Consistometer operating oil-well pressure, and temperature conditions were simulated at $2000 \mathrm{psi}$, and $140^{\circ} \mathrm{F}$, respectively. The results obtained evidenced that the medium density mixture is the optimum mixture. The medium density has the highest TT of 6.00 and 5.63 hours for with, and without retarder, respectively. Also from the results obtained, it evidenced that the addition of barite and water into the slurry slowed the geopolymerization hydration reaction. Additionally, it was discovered that the addition of retarder delayed the TT of the slurry by $6.49 \%$, $6.57 \%$ and $1.12 \%$ for low, medium and high density cement slurries, respectively. On the other hand, the addition of retarder was very insignificant in the high density slurry; this explained that the addition of barite hindered the retarder to form a barrier layer around the reacting geopolymer cement molecules. As a result of the study, Kanesan et al. (2018) concluded that, the three formulated geopolymer cement slurries met the requirements of conventional oil-well cementing processes with the TT falling between 3-8 hours, though depending on the well depth. In addition, it was also concluded that, the density of the cement slurry, and the addition of retarder affected the TT of the 
geopolymer cement slurries; which the medium density cement slurry resulted in the longest TT period. Conversely, the addition of retarders and barite were observed to be ineffective in prolonging the TT of high density cement slurries. Finally, it was found that the addition of retarder contributed to less than $10 \%$ of the increment in TT for all three cement densities formulated. This was also pointed out by Bett (2010) that, when a cement slurry density is reduced the TT and the ultimate compressive strength are also reduced. Kanesan et al. (2018) study also shows that, quantity of mixwater above the API Specification used in the formulation of cement slurry, does not only reduces the density of cement slurry, but prolongs or retards the TT of cement slurry. This premise about the effects of large quantity of mix-water in cement slurry on the performances of OWC TT has been confirmed by various studies (Valic and Stepisnic, 1998; Zhang et al., 2010).

Water is an important integral ingredient of cement slurry, and it is termed mix-water in cementing of oil and gas wells. Part of the mix-water is used in the hydration reaction of slurry cement, which a potable mix-water is required for imparting the workability of cement slurry into cement sheath. This is the singular reason most organisational specifications endorsed the use of potable mix-water for primary cementing (API Specification 10A, 1995; WHO, 2011). Thus, the quality of mix-water is always required, to be looked into very carefully; since, mix-waters are still collected at rig-site for the purposes of cementing without, the application of water-reticulation This have led to many reported cases of failed TT of cement slurry, due to the presence of chemical impurities in mix-water (Nygaard et al., 2014; Kiran, et al., 2017). Hence, the effects of mix-water quality on the TT performances of cement slurries have been investigated by many studies, but to no avail or consensus. On this background, Madhusudana et al. (2011) studied the effects of lead ion $\left(\mathrm{Pb}^{+}\right)$present in deionized mix-water of known concentrations on cement mortars properties. In the study, samples of cement mortars were prepared with de-ionized water at identified concentration of $\mathrm{Pb}^{+}$at $10,50,100$, $500,1000,2000,3000,4000$ and $5000 \mathrm{mg} / \mathrm{L}$; while some cement mortar samples were also prepared with de-ionized mix-water only. Those with the deionised water only, were used as the experimental control units, or for reference purposes. When the TT results of the reference sample were

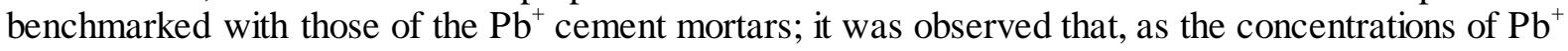
in mix-water increased, the TT of cement mortar significantly accelerated. Although, at $2000 \mathrm{mg} / \mathrm{L}$ concentration of $\mathrm{Pb}^{+}$, the TT slightly increased. However, this investigation was conducted at atmospheric conditions not at HPHT environment. Furthermore, Patil et al. (2011) in a study, examined the effects of chemicals as impurities in mix-water on properties of concrete. This work was conducted for cement mortars with w/c of 0.473 , using mix-water with various concentrations of sodium hydroxide $(\mathrm{NaOH})$, calcium hydroxide $(\mathrm{Ca}(\mathrm{OH}))_{2}$, calcium sulphate $\left(\mathrm{CaSO}_{4}\right)$, ferrous sulphate $\left(\mathrm{FeSO}_{4}\right)$, and sodium nitrate $\left(\mathrm{NaNO}_{3}\right)$. The recorded TT results showed that, the presence of each of the aforementioned chemical impurities in mix-water at increasing known concentrations, accelerated the TT of the investigated cement mortars, when compared with the control cement slurry prepared with Tap water only. Nevertheless, this investigation was accompanied at atmospheric conditions, not at HPHT environment. Similarly, in a recent study, Saleh et al. (2018) studied and measured how mix-water quality affects cement properties. As a result, five (5) different types of mix-waters classified as soft (distilled water), slightly-hard, moderately-hard, hard, and very-hard, were used in the formulation of the Class G OWC slurries. Thereafter, each of the slurries was subjected to the consistometer test, to record the TT. The results obtained from the study demonstrated that, when the hardness of the mix-water increased, the TT of the cement slurry accelerated. This investigation was carried out at simulated well conditions.

Generally, the aforementioned reviewed studies have evidenced that, the downhole temperature and pressure, improper use of additives, and chemical impurities in mix-water accelerates the thickening time of cement slurry, and mortar. Still, these evidences did not give account on the effects of density increment or reduction by ferrous ionic impurities on TT; and the effects of ferrous ion presence in mix-water on the thickening time performance of cement slurry in HPHT environment. Therefore, this research paper experimentally examined the effects of different ferrous ion known concentrations in mix-water, on the thickening time performance of cement slurry. Consequently, mix-water samples were collected between November, 2018 and March, 2019. To achieve this aim, this study randomly collected the mix-water samples from eight (8) boreholes at different locations of the study area, Kolo Creek, Nigeria. These sampled mix-waters were subjected to water analysis, to identify the physicochemical properties of the mix-waters. Furthermore, these analysed mix-waters were used in the formulation of Class $G$ oil-well cement slurry. In addition, deionised water was used in the 
preparation of the control cement slurry. Thereafter, each of the prepared slurries was subjected to HPHT TT performance test. In this study, the simulated HPHT environments were set in pairs of 3,000 psi and $250^{\circ} \mathrm{F} ; 3,000$ psi and $200^{\circ} \mathrm{F} ; 2,500$ psi and $250^{\circ} \mathrm{F} ; 2,500$ psi and $200^{\circ} \mathrm{F}$ for the TT performance tests.

\subsection{Study area}

The research opted for Kolo Creek area as a case study, because of the high activities of oil exploration and production, including the high content of ferrous groundwater in the area (Amangabara and Ejenma, 2012; Adesuyi, 2015; Oyinkuro and Rowland, 2017). Kolo Creek is located in Ogbia Local Government Area of Bayelsa State, Nigeria (Figure 1). Kolo Creek on the Global Positioning System (GPS) position is approximately at Latitude 04 $24^{\prime} 26.893^{\prime \prime}$ and $04^{\circ}$ $59^{\prime} 05.094^{\prime \prime}$ North and longitude $06^{\circ} 14^{\prime} 59.190^{\prime \prime}$ and $06^{\circ} 20^{\prime} 47.701^{\prime \prime}$ East, which an exploration and production company, had since 1964 been the sole international oil company (IOC) that operates the oil mining leases (OMLs) of between 35 and 36 (Adesuyi, 2015; Ebuete and Bariweni, 2019). The major hydrocarbon produced from this area is crude oil. As at 2016, more than 40-well have been drilled, which more than 33-well have been in the level of drilling and completion, and production. These oil-wells are classified at maximum pressure $(10,000 \mathrm{psi})$ and temperature $\left(300^{\circ} \mathrm{F}\right)$ see Figures 2 and 3; while the groundwater in this area, from shallow wellbores were classified as good, but not potable (Figure 4). Currently, more than 8-well are producing, in which 6-well are producing to Gbaran oil gathering facility (World Industrial Information, 2016). In addition, based on my personal conversations with several Community Leaders at Kolo Creek (Otuasaga, Oruma, Imiringi, Amurukani, Kolo 1, Kolo 2, Kolo 3, Emeyal 1, Emeyal 2, etc.) communities and staff of the IOC, it was disclosed that, the IOC do always conduct some remedial (maintenance) cementing jobs on some production wells. Therefore, this study is very paramount. Thus, this study is expected, to yield sustainable outcomes and solutions that would make the cementing of similar oil-wells safer and economically viable in the area.

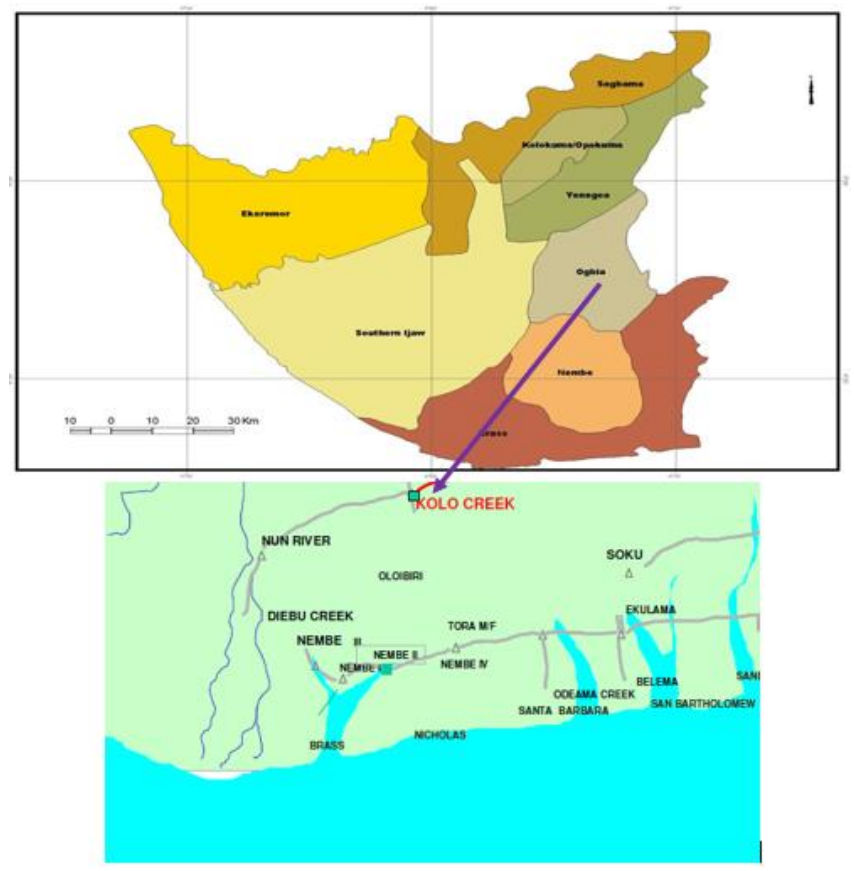

Figure 1: Map of Bayelsa State: inset map showing location of studied area (Kolo Creek) in red-like colour. Modified from Creek (2004) and Adesuyi (2015). 


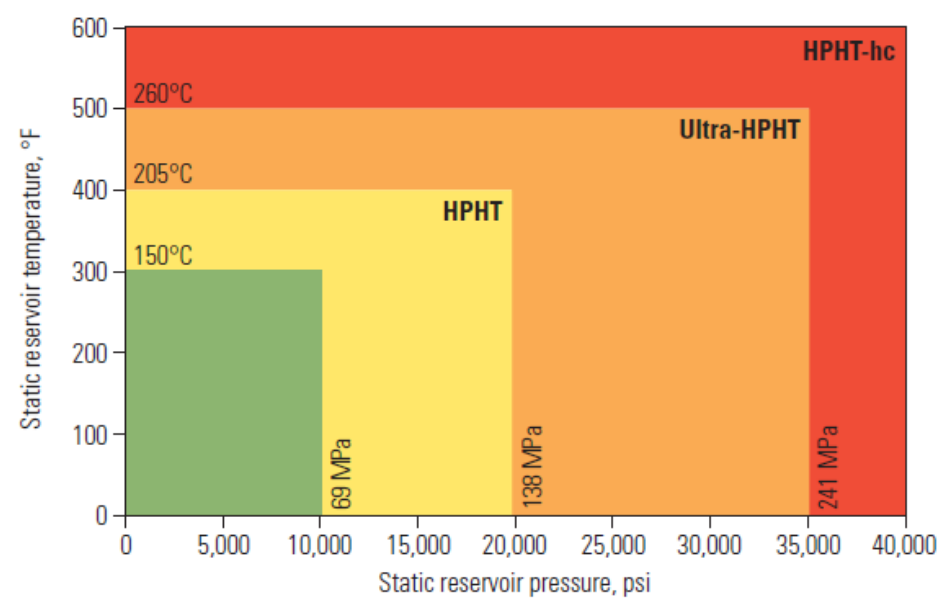

Figure 2: HPHT threshold classification for reservoirs (DeBruijn et al., 2008).

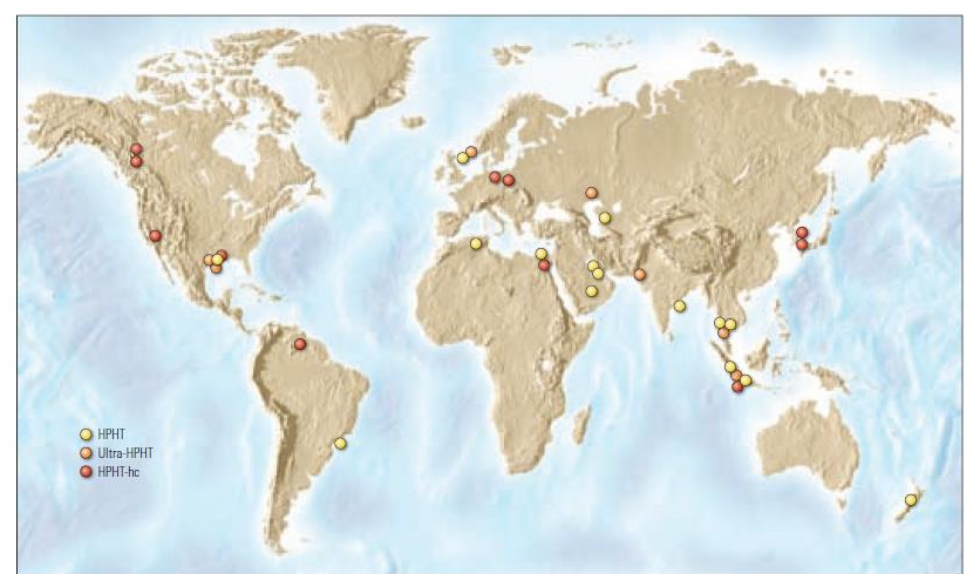

Figure 3: HPHT projects around the world (DeBruijn et al., 2008).

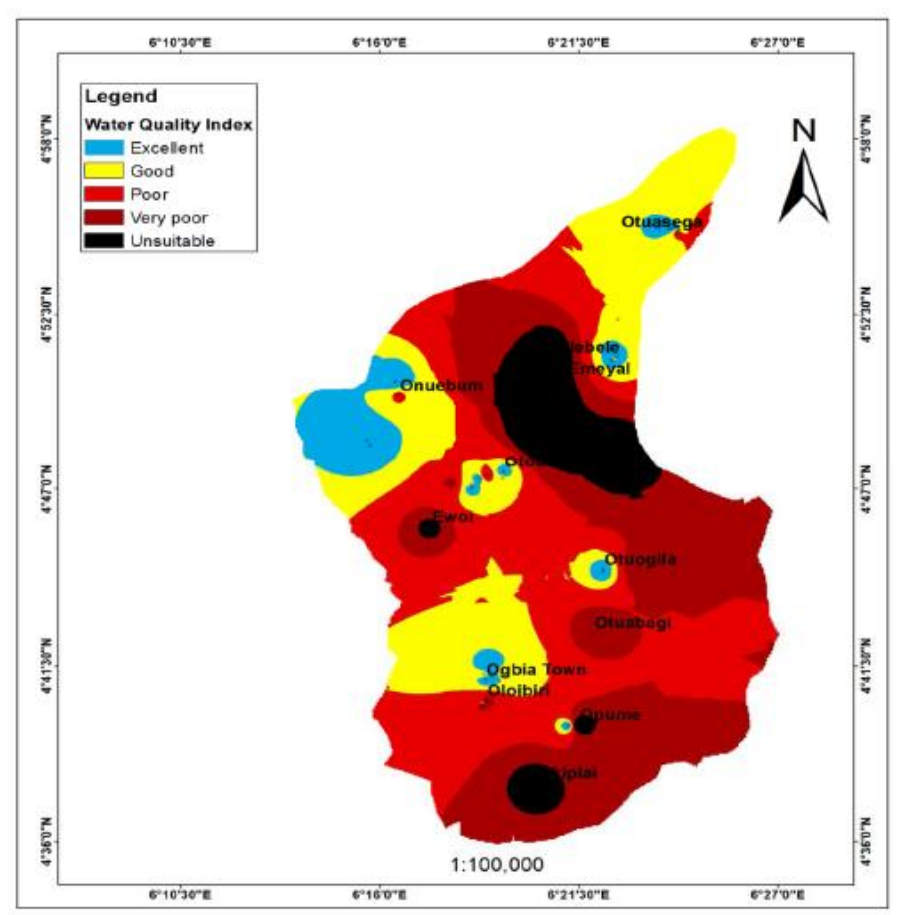

Figure 4: Water quality index map for Kolo Creek in Ogbia local government area, Bayelsa State, Nigeria (Oyinkuro and Rowland, 2017). 


\subsection{Methodology}

\subsection{Materials/equipment}

The materials used for the investigations were Class $G$ cement, de-ionised water, eight (8) ferrous mix-water samples, 36 cement slurry samples; while the major equipment were Weighing Balance, Pressurised Mud Balance, the Chandler model 7322 HPHT Pressurised Consistometer, X-ray diffraction (XRD), Quantachrome Autosorb-1 (QA) 2005 Surface Area Analyser and Cement Mixer.

\subsubsection{Deionized mix-water}

A 20-litre plastic-can of high grade de-ionized water was purchased from an industrial chemical Dealer at Yenagoa, Bayelsa State of the Federal republic of Nigeria. The deionised water was branded as ultra-violet treated and premium water quality. The deionised water was also laboratory graded and not intended for human consumption. The deionized water is a product of Roshan industries. The deionised mix-water was used, to formulate the neat cement slurries. This water is free from ions and impurities, and it was used, to formulate the control cement slurries for the TT tests.

\subsubsection{Sampling of mix-water}

The mix-water samples were collected between November, 2018 and March, 2019. The mix-water samples were randomly collected from eight (8) locations in the study area, Kolo Creek, Nigeria, as indicated in Table 1. Before the sampling processes were conducted, each sampling from the boreholes was conducted after the in-situ mix-water had been hovered from the borehole for 20 minutes. This was done with the aid of a submersible pump, at the flow rate (Q) of 20 litres/minutes. This ensured that the sampling was from the desired uncontaminated water-source in each water boreholes. Each of the boreholes had a depth that is approximately below $60 \mathrm{ft}$. After the 20 minutes of pumping, each of the 4-litre empty plastic container were washed and rinsed twice (2) with the sample to be collected at the borehole site; though, at every borehole sites mix-water was collected and poured into a rinsed 4-litre empty plastic container (Figure 5); then, the container was closed hermetically, while avoiding the appearance of air bubbles. Each of the containers had a label indicating the date, time, and location of the sample collected. The mix-water samples were transported in eight thermos-coolers to the Niger Delta University Chemistry Laboratory for water chemistry analysis.

Table 1: Sampled ferrous mix-water locations from case study area, Kolo Creek.

\begin{tabular}{|c|c|c|c|}
\hline S/No & $\begin{array}{c}\text { Water } \\
\text { Samples }\end{array}$ & Location & GPS Location \\
\hline 1 & WS1 & Deionised Water & Nil \\
\hline 2 & WS2 & Kolo 2 Izogbo & $4^{0} 48^{\prime} 20^{\prime \prime} 6^{0} 22^{\prime} 33^{\prime \prime} \mathrm{E}$ \\
\hline 3 & WS3 & Otuasege Otumisou & $4^{0} 552^{\prime} \mathrm{N}^{0} 2333^{\prime \prime E}$ \\
\hline 4 & WS4 & Kolo 2 Otu-ogele & $4^{0} 48^{2} 23^{\prime} \mathrm{N} 6^{0} 22^{\prime} 32^{\prime \prime E}$ \\
\hline 5 & WS5 & Otuasege Otuwododo & $4^{0} 55^{\prime} 5^{\prime N} 6^{0} 2339^{\prime \prime} \mathrm{E}$ \\
\hline 6 & WS6 & Kolo 1 Emelala & $4^{0} 48^{2} 23^{\prime} 6^{0} 22^{\prime} 32^{\prime \prime E}$ \\
\hline 7 & WS7 & Otuasege winners & $4^{0} 5451^{\prime} \mathrm{N}^{0} 237 \mathrm{E}$ \\
\hline 8 & WS8 & Oruma Ebifro & $4^{0} 552 \mathrm{~N} 6^{0} 2411 \mathrm{E}$ \\
\hline 9 & WS9 & Kolo 2 Angala & $4^{0} 48^{2} 22^{\mathrm{N}} 6^{\circ} 22^{\prime} 32^{\prime \prime} \mathrm{E}$ \\
\hline
\end{tabular}

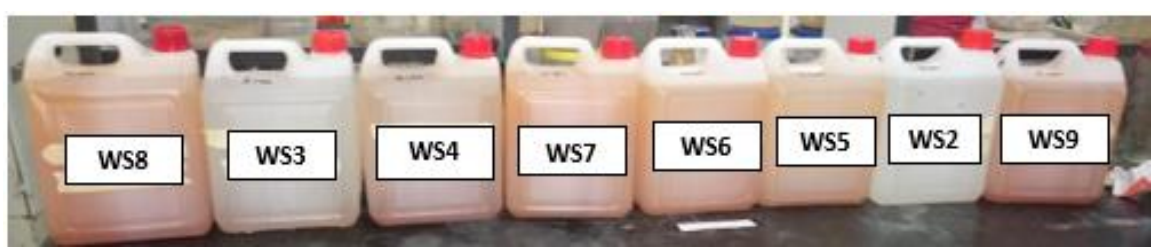

Figure 5: 30 days stand-alone sampled mix-water from the case study area, Kolo Creek.

2.1.3. Mix-water and its physicochemical properties

The mix-water samples were collected between November, 2018 and March, 2019. These mix-water samples were randomly collected from eight (8) boreholes at different locations of the study area, 
Kolo Creek, Nigeria. These sampled mix-waters were subjected to water analysis, to identify the physicochemical properties of the mix-water. The mix-water samples randomly collected from the 8 locations in the study area, Kolo Creek, were subjected to water analysis, at the Chemistry Laboratory, Niger Delta University, Nigeria. These laboratory analyses were conducted in agreement with the widely accepted conventional instrumental analytical standard methods of the American Public Health Association drinking water test methods (APHA, 1998). The instrumental analytical standard methods were used, to test for the presence of some heavy metals in each of the sampled mix-waters at the laboratory, after 3 hours of sampling. The heavy metals investigated were limited to: arsenic (As), chlorine $(\mathrm{Cl})$, cadmium $(\mathrm{Cd})$, chromium $(\mathrm{Cr})$, copper $(\mathrm{Cu})$, iron $(\mathrm{Fe})$, lead $(\mathrm{Pb})$, magnesium $(\mathrm{Mg})$, calcium $(\mathrm{Ca})$, mercury $(\mathrm{Hg})$, and zinc $(\mathrm{Zn})$. Explicitly, the presence of heavy metals in the mix-water samples were determined by the Atomic Absorption Spectrophotometer (AAS); while the anion, and cation of the heavy metals were measured and determined using standard titrimetric and spectrophotometric methods. Furthermore, other physical properties of the mix-water samples examined onsite, were the $\mathrm{pH}$, turbidity, total dissolved solids (TDS), and electrical conductivity. Subsequently, the physicochemical results obtained were benchmarked with the World Health Organisation, and Nigeria Standard Drinking Water Quality standards values (NSDWQ, 2007; WHO, 2011). The physicochemical results show that, in each of the tested mix-water samples for physicochemical parameters, the ferrous ion $\left(\mathrm{Fe}^{2+}\right)$ concentration was higher $(0.52$ to $6.82 \mathrm{mg} / \mathrm{L})$; which is greater than $0.3 \mathrm{mg} / \mathrm{L}$ (Table 2). This was the only heavy metal that is strongly in disagreement with the WHO's and NSDWQ's Drinking Water Quality standards. However, groundwater from this study area, have been declared as good water, but not as potable water (Oyinkuro and Rowland, 2017). The aforementioned laboratory tests and analyses for physicochemical parameters of water to determine its suitability as potable water, have also been used and reported by many researchers (Ashraf et al., 2011; Oyinkuro and Rowland, 2017; Zacchaeus et $a l ., 2020)$; hence, its application in this study.

Table 2: Results of physicochemical on the mix-water samples collected between November, 2018 and March, 2019 from Kolo Creek

\begin{tabular}{|c|c|c|c|c|c|c|c|c|c|c|c|c|c|c|c|c|c|c|}
\hline & & & & $\mathrm{Fe}$ & $\mathrm{Pb}$ & Mg & $\mathrm{Hg}$ & $\mathrm{Ca}$ & As & $\mathrm{Cd}$ & $\mathrm{Cr}$ & $\mathrm{Cu}$ & $\mathrm{Zn}$ & $\mathrm{Cl}$ & $\mathrm{pH}$ & 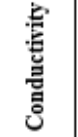 & $\begin{array}{l}\text { 点 } \\
\text { 总 } \\
\text { 晋 }\end{array}$ & 目 \\
\hline & & & Units & \multicolumn{11}{|c|}{$\mathrm{mg} / \mathrm{L}$} & Unitless & $\mu \mathrm{S} / \mathrm{cm}$ & NTU & $\mathrm{mg} / \mathrm{L}$ \\
\hline \multicolumn{4}{|c|}{ WHO (2011) PERMIISSIBLE LIMIT } & 0.3 & 0.01 & - & 0.006 & 75 & 0.01 & 0.003 & 0.05 & 2 & - & 250 & $6.5-8.5$ & - & 5 & 500 \\
\hline \multicolumn{4}{|c|}{ NSDWQ (2007) PERMIISIBLE LIMIT } & 0.3 & 0.01 & 150 & 0.001 & 75 & 0.01 & 0.003 & 0.05 & 1 & 3 & 250 & $6.5-9.0$ & 1000 & - & 500 \\
\hline S/No & $\begin{array}{l}\text { Water } \\
\text { Samples }\end{array}$ & $\begin{array}{l}\text { Location at } \\
\text { Kolo Creek }\end{array}$ & $\begin{array}{c}\text { GPS } \\
\text { Location }\end{array}$ & \multicolumn{11}{|c|}{$\begin{array}{l}\text { This Research Laboratory Results of the Chemical } \\
\text { Analyses on the Mix-Water Samples }\end{array}$} & \multicolumn{4}{|c|}{$\begin{array}{l}\text { This Research Onsite Results of the } \\
\text { Physical Analyses on the Mix-Water } \\
\text { Samples }\end{array}$} \\
\hline 1 & wS1 & $\begin{array}{c}\text { Deionised } \\
\text { Water }\end{array}$ & Nil & 0.00 & 0.00 & 0.00 & 0.00 & 0.00 & 0.00 & 0.00 & 0.00 & 0.00 & 0.00 & 0.00 & 7.00 & 0.05 & 0.00 & 0.00 \\
\hline 2 & WS2 & $\begin{array}{l}\text { Kolo } 2 \\
\text { Izogbo }\end{array}$ & $\begin{array}{l}4^{0} 48^{\prime} 20^{\prime \prime} \mathrm{N} \\
6^{0} 2233^{\prime \prime} \mathrm{E}\end{array}$ & 0.52 & 0.00 & 4.10 & 0.00 & 5.90 & 0.00 & 0.00 & 0.00 & 0.00 & 0.00 & 23.00 & 7.10 & 75.00 & 1.10 & 91.00 \\
\hline 3 & wS3 & $\begin{array}{l}\text { Otuasege } \\
\text { Otumisou }\end{array}$ & $\begin{array}{l}4^{0} 55^{2} 2 \mathrm{~N} \\
6^{0} 23^{\prime} 33^{\prime \prime} \mathrm{E}\end{array}$ & 0.73 & 0.00 & 7.10 & 0.00 & 9.05 & 0.00 & 0.00 & 0.00 & 0.00 & 0.00 & 21.00 & 7.20 & 55.50 & 1.10 & 92.50 \\
\hline 4 & WS4 & $\begin{array}{l}\text { Kolo } 2 \text { Otu- } \\
\text { ogele }\end{array}$ & $\begin{array}{l}4^{0} 48^{\prime} 23^{\prime \prime} \mathrm{N} \\
6^{0} 2232^{\prime \prime} \mathrm{E}\end{array}$ & 3.80 & 0.00 & 4.10 & 0.00 & 6.00 & 0.00 & 0.00 & 0.00 & 0.00 & 0.00 & 25.00 & 6.95 & 80.00 & 1.40 & 99.00 \\
\hline 5 & wS5 & $\begin{array}{c}\text { Otuasege } \\
\text { Otuwododo }\end{array}$ & $\begin{array}{l}4^{0} 55^{\prime} 5 \mathrm{~N} \\
6^{0} 23^{\prime} 39^{\prime \prime} \mathrm{E}\end{array}$ & 5.00 & 0.00 & 2.05 & 0.00 & 5.70 & 0.00 & 0.00 & 0.00 & 0.00 & 0.00 & 10.00 & 6.85 & 175.00 & 1.50 & 88.00 \\
\hline 6 & WS6 & $\begin{array}{c}\text { Kolo } 1 \\
\text { Emelala }\end{array}$ & $\begin{array}{l}4^{0} 48^{\prime} 23^{\prime \prime} \mathrm{N} \\
6^{0} 222^{\prime \prime} \mathrm{E}\end{array}$ & 5.20 & 0.00 & 4.20 & 0.00 & 8.50 & 0.00 & 0.00 & 0.00 & 0.00 & 0.00 & 25.50 & 6.85 & 85.00 & 1.50 & 100.00 \\
\hline 7 & wS7 & $\begin{array}{c}\text { Otuasege } \\
\text { winners }\end{array}$ & $\begin{array}{c}4^{0} 54^{\prime} 51^{\prime \prime N} \\
6^{0} 23^{\prime} 7^{\prime \prime} \mathrm{E}\end{array}$ & 5.53 & 0.00 & 3.50 & 0.00 & 8.90 & 0.00 & 0.00 & 0.00 & 0.00 & 0.00 & 15.00 & 6.80 & 254.00 & 1.55 & 128.00 \\
\hline 8 & wS8 & $\begin{array}{l}\text { Oruma } \\
\text { Ebifro }\end{array}$ & $\begin{array}{l}4^{0} 552 \mathrm{~N} \\
6^{0} 24^{1} 11^{11} \mathrm{E}\end{array}$ & 6.35 & 0.00 & 6.10 & 0.00 & 7.50 & 0.00 & 0.00 & 0.00 & 0.00 & 0.00 & 15.00 & 6.90 & 76.00 & 1.60 & 96.00 \\
\hline 9 & WS9 & $\begin{array}{l}\text { Kolo } 2 \\
\text { Angala }\end{array}$ & $\begin{array}{l}4^{0} 48^{2} 22^{\prime} \mathrm{N} \\
6^{0} 22^{3} 32^{\prime \prime} \mathrm{E}\end{array}$ & 6.82 & 0.00 & 4.10 & 0.00 & 6.50 & 0.00 & 0.00 & 0.00 & 0.00 & 0.00 & 27.50 & 6.80 & 90.00 & 1.60 & 110.00 \\
\hline
\end{tabular}

\subsubsection{Class G oil-well cement}

Class G oil-well cement was used as one of the experimental materials. This Class G oil-well cement was provided by a Vendor to the petroleum engineering laboratory, Niger Delta University, Nigeria. Class G oil-well cement (OWC) is envisioned for use as oil and gas basic cement. Upon its delivery at the petroleum engineering laboratory, the cement was packed separately in sealed plastic bags. These sealed bags were further sealed in five (5) empty 20 -litre plastic cans with each container containing $5 \mathrm{~kg}$ of the Class G OWC, to prevent the powdered cement from contacting moisture. To 
verify this cement, X-ray diffraction (XRD) and Quantachrome Autosorb-1 (QA) 2005 Surface Area Analyser equipment were used, to test for the composition and surface area of the Class G OWC. The results from both the QA, and XRD tests are summarised and presented on Table 3. In addition, the surface area of the Class G OWC was measured by the Brunauer, Emmett, and Teller (BET) method using nitrogen gas as the adsorptive medium in a QA 2005 (Khan et al., 2010). The XRD and BET preliminary results disclosed that the $\mathrm{Al}_{2} \mathrm{O}_{3}$ to $\mathrm{Fe}_{2} \mathrm{O}_{3}$ weight ratio was greater than 0.64 (Bourgoyne $e t$ al., 1986). This explained that, the supplied Class $\mathrm{G}$ cement is suitable in formulating the deionised and ferrous cement slurry systems for the investigations. More information about the Class $\mathrm{G}$ cement specifications are presented in Tables 4 and 5.

Table 3: Compound component and BET surface area of class G oil-well cement (wt.\%).

\begin{tabular}{|c|c|c|c|c|c|c|}
\hline \multirow{2}{*}{ CEMENT TYPE } & \multicolumn{5}{|c|}{ MAJOR COMPONENTS } & $\begin{array}{c}\text { SURFACE } \\
\text { AREA }\left(\mathrm{m}^{2} / \mathbf{g}\right)\end{array}$ \\
\hline & $\mathrm{C}_{8} \mathrm{~S}$ & $\mathrm{C}_{2} \mathrm{~S}$ & $\mathrm{C}_{3} \mathrm{~A}$ & $\mathrm{C}_{4} \mathrm{AF}$ & Gypsum & BET Method \\
\hline $\begin{array}{c}\text { Class G Oilwell } \\
\text { Cement }\end{array}$ & 62.93 & 14.82 & 0.57 & 11.34 & 1.8 & $1.00 \pm 0.0075$ \\
\hline
\end{tabular}

Table 4: Major chemical properties of class G oil-well cement

\begin{tabular}{|c|c|c|}
\hline S/No. & Parameter/Unit & Value \\
\hline 1. & Loss on ignition, $\%$ & 0.80 \\
\hline 2. & Insoluble residue, \% & 0.42 \\
\hline 3. & $\mathrm{Mg} \Omega_{0} \%$ & 2.0 \\
\hline 4. & $\mathrm{C}_{3} \mathrm{~S}, \%$ & 63 \\
\hline 5. & $\mathrm{C}_{2} \mathrm{~S}, \%$ & 14.80 \\
\hline 6. & $\mathrm{C}_{3} \mathrm{~A}, \%$ & 2.2 \\
\hline 7. & $\mathrm{C}_{4} \mathrm{AF}+2 \mathrm{C}_{3} \mathrm{~A}, \%$ & 18 \\
\hline 8. & Gypsum, \% & $<1.8$ \\
\hline 9. & Alkali content expressed as $\mathrm{Na}_{2} \mathrm{O}, \%$ & 0.66 \\
\hline 10 & $\mathrm{SO}_{3}, \%$ & 1.65 \\
\hline
\end{tabular}

Table 5: Physical properties of class G oil-well cement

\begin{tabular}{|c|c|c|}
\hline S/No. & Parameter/Unit & Value \\
\hline 1. & Specific Gravity, unitless & 3.14 \\
\hline 2. & Surface Area, $\mathrm{m}^{2} / \mathrm{g}$ & 1.00 \\
\hline 3. & Bulk Weight, lbs./ft ${ }^{3}$ & 3.14 \\
\hline 4. & Water for standard consistency [(Water $(\mathrm{g}) /$ Cement $(\mathrm{g})^{\star} \%$ ] & 0.44 \\
\hline 5. & Initial Setting Time at atmospheric condition, minutes & 30 \\
\hline 6. & Final Setting at atmospheric condition, minutes & 600 \\
\hline 7. & Minimum Thickening Time, minutes & 90 \\
\hline 8. & Maximum Thickening Time, minutes & 120 \\
\hline 9. & Thickening Time + Additives to enable placement in $\mathrm{HJ}_{0}{ }^{\circ} \mathrm{F}$ & 550 \\
\hline 10 & Maximum Consistency Between $15-30$ minutes, Bearden $\left(\mathrm{B}_{\mathrm{c}}\right)$ & 30 \\
\hline 11 & $\begin{array}{l}\text { Minimum Compressive Strength at curing: time (8hrs), } \\
\text { temperature }\left(100^{\circ} \mathrm{F}\right) \text {, and Atmos. pressure, psi }\end{array}$ & 300 \\
\hline 12 & $\begin{array}{l}\text { Maximum Compressive Strength at curing: time (8hrs), } \\
\text { temperature }\left(140^{\circ} \mathrm{F}\right) \text {, and Atmos. pressure, psi }\end{array}$ & 1,500 \\
\hline 13 & Depth Usage as Neat Cement Slurry, ft. & $\approx 8,000$ \\
\hline 14 & Depth Usage when mixed with Additives, ft. & $>8000$ \\
\hline 15 & Response to Retarders, unitless & Excellent \\
\hline 16 & Free water content, $\mathrm{mL}$ & 4.3 \\
\hline 17 & Soundness, , $\%$ & 0.08 \\
\hline
\end{tabular}




\subsection{Methods}

2.2.1. Preparation of ferrous and deionised Class G cement slurry

The sampled ferrous mix-waters were used to prepare the cement slurries. Practically, these cement slurries were prepared based on the principles of API specification 10A (API specification 10A, 1995). In accordance with this specification, the container with mix-water as its content was subjected to mixing at the speed of 4,000 rpm for approximately 15 seconds; after all the measured Class $\mathrm{G}$ cement powder had been added into the mix-water, immediately the mixing container was covered and placed for mixing at the speed of 12,000 rpm in the cement-mixer. This mixing was performed for about 35 seconds. Explicitly, from the both 8 samples of ferrous mix-waters, and 1 sample of de-ionised mix-water; cement slurries were formulated, at various performance test intervals. Generally, eight (8) cement slurries of mix-water/oil-well Class G cement ratios (w/c) of 0.44 were prepared from each of the 8 different mix-waters, which had different ferrous ions concentrations; and one (1) deionised cement slurry for the control experiment (Figure 6). A total of 36 cement slurry samples were used for the TT tests. Also, precautions were taken, to ensure the adherence of the API procedures of mixing cement slurry, and the replacement of the device's blade, when it has loss $10 \%$ of its original weight with an unused standard blade.

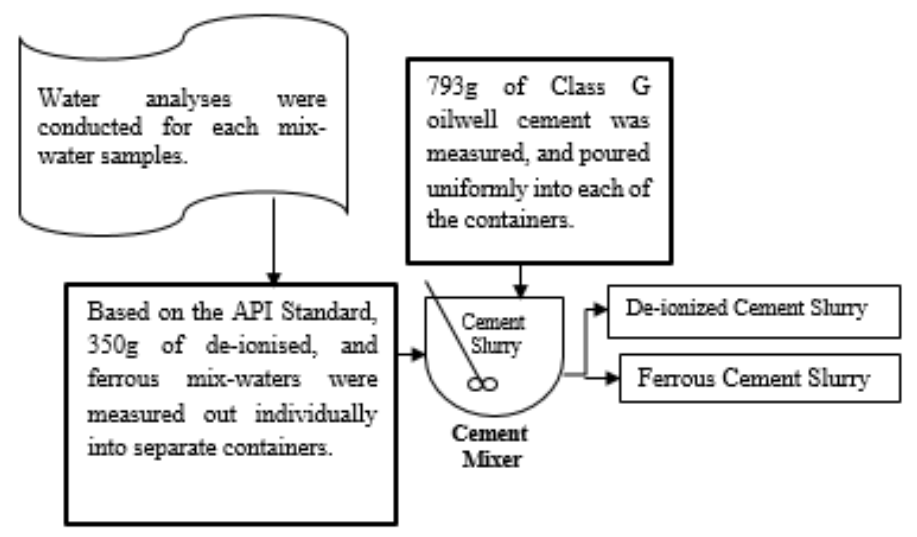

Figure 6: Block diagram illustrating the preparation of cement slurries for the tests

\subsubsection{Thickening test of ferrous Class G cement slurry}

The outcome of the laboratory TT tests evidenced the length of time that the ferrous Class G cement slurry would remain pumpable or flowable in the wellbore annulus at the simulated high-pressure and high-temperature (Roshan and Asef, 2010). This is also termed the time waiting-on-cement (WOC) to set. This includes the initial mixing time of the cement slurry, to the time the cement slurry can no longer be pumped in the wellbore, during the cementing of the annulus between the casing and the formation wall. In investigating these ferrous cement slurries, in the laboratory, these tests were performed in a Chandler HPHT Consistometer model 7322, and readings were taken, at some points, and at the stationary condition $\left(30,70\right.$, and $100 \mathrm{~B}_{c}$ ) of the potentiometer (API Specification 10A, 1995; Salam et al., 2013; Alp and Akin, 2013; Broni-Bediako et al., 2015). These readings were reported or expressed in Bearden units of consistency, $B_{c}$ (API Specification 10A, 1995). In this study, the operational testing pressure and temperature were set in pairs of $3,000 \mathrm{psi}$ and $250^{\circ} \mathrm{F} ; 3,000$ psi and $200^{\circ} \mathrm{F} ; 2,500$ psi and $250^{\circ} \mathrm{F} ; 2,500$ psi and $200^{\circ} \mathrm{F}$. These experimental controlled conditions were used to examine and estimate the TT of each of the 36 formulated ferrous cement slurries, divided in four (4) experimental groups, which each group had eight (8) ferrous cement slurry samples. The ferrous cement slurry samples used for the tests were neat ferrous Class G cement slurries, which contained low to high ferrous concentration in mix-water and Class G oil-well cement. Practically, after the preparation of each of the samples, the investigated sample was filled into the two (2) API cement slurry cups, to the groove marked positions. Then, approximately after 20 seconds, the outside of the slurry containers were struck by a lighter rod to remove all entrapped air pockets from the prepared cement slurry. At this point, the stationary paddles assembly including the potentiometer were inserted into each of the slurry containers, and installed into the opened cylindrical housing. Then, the consistometer was powered, and white mineral oil was supplied, and circulated into the bath-oil pressure chamber. This supplied oil was controlled with the gland nut, to attain the pressurised consistometer desired bath-level. The desired bath-level was observed and attained, when the oil started flowing after the air in the exhaust. This made the air-operated 
hydraulic pump, to generate pressure to the cylinder assembly; after the gland nut was tightened firmly. Afterward, the simulated pressure and temperature were set to $3,000 \mathrm{psi}$ and $250^{\circ} \mathrm{F}$, respectively. Also, the setting of simulated temperature actuated the heat, which was supplied to the chamber by a 2,200 watt, internal, tubular heater; while the thermocouples determined the temperatures of the oil bath and cement slurry at an increasing temperature gradient of $3^{0} \mathrm{~F}$ (Igbani $e t$ $a l ., 2020)$. The alarm system was also set at $90 \mathrm{~min}$, to remind the Researcher about the minimum 90 min API TT of Class G cement, these configurations took about $5 \mathrm{~min}$. Consequently, the heater, motor and timer clock were finally turned on; the motor rotated the API slurry cups via the drive table, at a speed of about $150 \mathrm{rpm}$; while the operating time for the test was set at $145 \mathrm{~min}$. Then, the maximum consistency $\left(\mathrm{B}_{c}\right)$ during the conditioned time of $15-30$ min after the initiation of the TT; and the time the formulated ferrous cement slurry got to the consistency of 30,70 and $100 \mathrm{~B}_{c}$ were recorded. At the end of the testing period, the controller was stopped.

Finally, after the consistometer had been depressurised, oil-drained, and allowed to cool down, the aforementioned experimental procedure was repeated for each of the cement slurry samples prepared, according to the stipulated experimental conditions. The TT results are presented in the next section for analyses, and discussions.

\subsection{Results and Discussion}

Tables 6 to 9 show the different ferrous ion concentration in mix-waters, as it affects the TT of the investigated cement slurry systems. In each of the tables, column A, B, C, D, E, F, and G depicts the sample label (mix-water sample [MWS]), ferrous ion concentration $(\mathrm{mg} / \mathrm{L})$, density of the cement (ppg), and the API first 15-30 minutes in consistency $\left(\mathrm{B}_{\mathrm{c}}\right)$, while the others represent the TT at the consistency of $30 \mathrm{~B}_{\mathrm{c}}, 70 \mathrm{~B}_{\mathrm{c}}$, and $100 \mathrm{~B}_{\mathrm{c}}$, respectively. The results in Table 6, Table 7, Table 8, and Table 9 were respectively obtained at the held paired simulated temperature and pressure of $250^{\circ} \mathrm{F}$ and $3000 \mathrm{psi} ; 200^{\circ} \mathrm{F}$ and $3000 \mathrm{psi} ; 250^{\circ} \mathrm{F}$ and $2500 \mathrm{psi} ; 200^{\circ} \mathrm{F}$ and $2500 \mathrm{psi}$. Consequently, the API first 15 - 30 minutes' consistency values, which range from 16.70 to $25.30 \mathrm{~B}_{\mathrm{c}}$ in column D of Tables 6 to 9, with higher values in Table 7, disclosed that, all the cement slurry samples tested, satisfied the API requirement for oil-well cement TT (Broni-Bediako et al., 2015; API Specification 10A, 1995). Although, most of these slurries are contaminated with $\mathrm{Fe}^{2+}$ ion. In addition, the results found in the aforementioned tables indicate that, as the concentration of $\mathrm{Fe}^{2+}$ ion (column B) increases at the rate of $0.93 \mathrm{mg} / \mathrm{L}$, the density of the cement slurry (column C) decreases at the rate of $-0.48 \mathrm{ppg}$. Sequel to this, detailed results have been presented in Figures 7, to illustrate the inverse proportional relationship between ferrous ion concentration and ferrous cement density, and how it affects the investigated TT at $30 \mathrm{Bc}, 70 \mathrm{Bc}$, and $100 \mathrm{Bc}$, of the neat ferrous cement slurry at the held paired simulated temperature and pressure of $250^{\circ} \mathrm{F}$ and $3000 \mathrm{psi}, 200^{\circ} \mathrm{F}$ and $3000 \mathrm{psi}, 250^{\circ} \mathrm{F}$ and $2500 \mathrm{psi}$, and $200^{\circ} \mathrm{F}$ and 2500 psi.

Table 6: $\mathrm{TT}$ at temperature $\left(250^{\circ} \mathrm{F}\right)$ and pressure $(3,000 \mathrm{psi})$ and cement density

\begin{tabular}{|c|c|c|c|c|c|c|}
\hline S/NO & \multirow{3}{*}{ 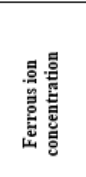 } & \multirow{3}{*}{ 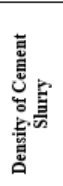 } & \multirow{2}{*}{\multicolumn{4}{|c|}{$\begin{array}{c}\text { RESPONSE SURFACES or DEPENDENT } \\
\text { VARIABLES } \\
\text { Thickening Time }\end{array}$}} \\
\hline \multirow{4}{*}{ 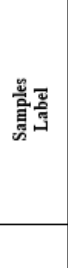 } & & & & & & \\
\hline & & & $\begin{array}{l}\text { API First } \\
15-30 \text { Minutes } \\
\text { Flow } \\
\text { Consistency }\end{array}$ & \multicolumn{3}{|c|}{$\begin{array}{c}\text { Flow Consistency@ } \\
\text { Flowing Time. }\end{array}$} \\
\hline & $\begin{array}{c}\begin{array}{c}\text { Fe2_Con } \\
(\mathrm{Mg} / \mathrm{L})\end{array}\end{array}$ & (ppg) & $\begin{array}{c}\text { Bearden } \\
\left(\mathbf{B C}_{\mathrm{c}}\right)\end{array}$ & \multicolumn{3}{|c|}{ Bearden (Bc) @ Time (Min.) } \\
\hline & & & & $30 \mathrm{~B}_{\mathrm{C}}$ & $70 \mathrm{~B}_{\mathrm{C}}$ & $100 \mathrm{~B}_{\mathrm{C}}$ \\
\hline A & B & C & D & E & F & G \\
\hline MWS1 & 0.00 & 18.30 & 21.00 & 58 & 96 & 106 \\
\hline MWS2 & 0.52 & 18.00 & 20.50 & 56 & 93 & 102 \\
\hline MWS3 & 0.73 & 17.10 & 20.45 & 55 & 92 & 101 \\
\hline MWS4 & 3.80 & 16.40 & 19.10 & 50 & 87 & 96 \\
\hline MWS5 & 5.00 & 15.50 & 19.00 & 44 & 84 & 95 \\
\hline MwS6 & 5.20 & 15.20 & 18.60 & 43 & 80 & 94 \\
\hline MWS7 & 5.53 & 15.10 & 18.20 & 42 & 79 & 93 \\
\hline Mwss & 6.35 & 15.05 & 17.40 & 40 & 78 & 91 \\
\hline MwS9 & 6.82 & 15.00 & 17.10 & 39 & 76 & 90 \\
\hline
\end{tabular}


Table 7: TT at temperature $\left(200^{\circ} \mathrm{F}\right)$ and pressure $(3,000 \mathrm{psi})$ and cement density

\begin{tabular}{|c|c|c|c|c|c|c|}
\hline \multirow{4}{*}{ 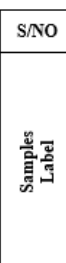 } & \multirow{3}{*}{ 高 } & \multirow{3}{*}{ 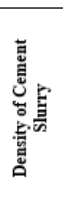 } & \multicolumn{4}{|c|}{$\begin{array}{c}\text { RESPONSE SURFACES or DEPENDENT } \\
\text { VARIABLES }\end{array}$} \\
\hline & & & \multicolumn{4}{|c|}{ Thickening Time } \\
\hline & & & $\begin{array}{c}\text { API First } \\
15-30 \text { Minutes } \\
\text { Flow } \\
\text { Consistency } \\
\text { (MAX }=30 B_{\text {B. }}\end{array}$ & \multicolumn{3}{|c|}{$\begin{array}{c}\text { Flow Consistency @ } \\
\text { Flowing Time. }\end{array}$} \\
\hline & $\begin{array}{l}\text { Fe2 Con } \\
(\text { (Mg/L) }\end{array}$ & (ppg) & $\begin{array}{c}\text { Bearden } \\
\left(B_{c}\right)\end{array}$ & \multicolumn{3}{|c|}{ Bearden (Bc) @ Time (Min.) } \\
\hline & & & & $30 \mathrm{~B}_{\mathrm{C}}$ & $70 \mathrm{~B}_{\mathrm{c}}$ & $100 \mathrm{~B}_{\mathrm{c}}$ \\
\hline A & в & $\mathrm{c}$ & D & E & $\mathbf{F}$ & G \\
\hline Mws1 & 0.00 & 18.30 & 25.30 & 65 & 106 & 116 \\
\hline MwS2 & 0.52 & 18.00 & 24.60 & 62 & 104 & 114 \\
\hline MWS3 & 0.73 & 17.10 & 24.50 & 61 & 102 & 113 \\
\hline MwS4 & 3.80 & 16.40 & 23.00 & 56 & 97 & 106 \\
\hline MwS5 & 5.00 & 15.50 & 22.80 & 50 & 92 & 106 \\
\hline Mws6 & 5.20 & 15.20 & 22.30 & 48 & 88 & 105 \\
\hline MWS7 & 5.53 & 15.10 & 21.80 & 48 & 87 & 104 \\
\hline Mwss & 6.35 & 15.05 & 20.80 & 46 & 86 & 102 \\
\hline Mws9 & 6.82 & 15.00 & 20.50 & 45 & 84 & 99 \\
\hline
\end{tabular}

Table 8: TT at temperature $\left(250^{\circ} \mathrm{F}\right)$ and pressure $(2,500 \mathrm{psi})$ and cement density

\begin{tabular}{|c|c|c|c|c|c|c|}
\hline \multirow{4}{*}{ 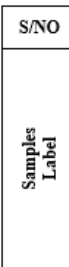 } & \multirow{3}{*}{ 总 } & \multirow{3}{*}{ 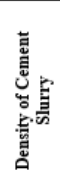 } & \multicolumn{4}{|c|}{$\begin{array}{l}\text { RESPONSE SURFACES or DEPENDENT } \\
\text { VARIABLES }\end{array}$} \\
\hline & & & \multicolumn{4}{|c|}{ Thickening Time } \\
\hline & & & $\begin{array}{c}\text { API First } \\
15-30 \text { Minutes } \\
\text { Flow } \\
\text { Consistency } \\
\text { (MAX }=30 \text { B. }\end{array}$ & \multicolumn{3}{|c|}{$\begin{array}{l}\text { Flow Consistency@ } \\
\text { Flowing Time. }\end{array}$} \\
\hline & $\begin{array}{l}\mathrm{Fe}^{\mathrm{Fe} \text { Con }} \\
(\mathrm{Mg} / \mathrm{L})\end{array}$ & (ppg) & $\begin{array}{c}\text { Bearden } \\
\left(\mathbf{B}_{C}\right)\end{array}$ & \multicolumn{3}{|c|}{ Bearden (Bc) @ Time (Min.) } \\
\hline & & & & 30B $\mathrm{c}$ & $70 \mathrm{~B}_{\mathrm{c}}$ & $100 \mathrm{Bc}$ \\
\hline A & B & $\mathrm{c}$ & D & E & F & G \\
\hline Mws1 & 0.00 & 18.30 & 20.50 & 60 & 100 & 110 \\
\hline MwS2 & 0.52 & 18.00 & 20.05 & 58 & 97 & 106 \\
\hline Mws3 & 0.73 & 17.10 & 20.00 & 57 & 96 & 105 \\
\hline MwS4 & 3.80 & 16.40 & 18.00 & 52 & 91 & 100 \\
\hline MwS5 & 5.00 & 15.50 & 18.50 & 50 & 83 & 98 \\
\hline Mws6 & 5.20 & 15.20 & 18.20 & 45 & 83 & 98 \\
\hline Mws7 & 5.53 & 15.10 & 17.30 & 44 & 82 & 97 \\
\hline Mwss & 6.35 & 15.05 & 17.10 & 42 & 81 & 95 \\
\hline Mws9 & 6.82 & 15.00 & 16.70 & 41 & 79 & 93 \\
\hline
\end{tabular}

Table 9: TT at temperature $\left(200^{\circ} \mathrm{F}\right)$ and pressure $(2,500 \mathrm{psi})$ and cement density

\begin{tabular}{|c|c|c|c|c|c|c|}
\hline S/NO & \multirow{3}{*}{ 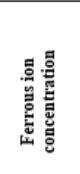 } & \multirow{3}{*}{ 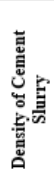 } & \multirow{2}{*}{\multicolumn{4}{|c|}{$\begin{array}{c}\text { RESPONSE SURFACES or DEPENDENT } \\
\text { VARIABLES } \\
\text { Thickening Time }\end{array}$}} \\
\hline \multirow{4}{*}{ 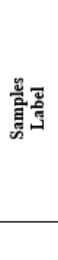 } & & & & & & \\
\hline & & & $\begin{array}{l}\text { API First } \\
15-30 \text { Minutes } \\
\text { Flow } \\
\text { Consistency }\end{array}$ & \multicolumn{3}{|c|}{$\begin{array}{c}\text { Flow Consistency @ } \\
\text { Flowing Time. }\end{array}$} \\
\hline & $\begin{array}{c}\begin{array}{c}\mathrm{Fe}^{2} \text { Con } \\
(\mathrm{Mg} / \mathrm{L})\end{array}\end{array}$ & (ppg) & $\begin{array}{c}\text { Bearden } \\
\left(\mathbf{B}_{\mathrm{C}}\right)\end{array}$ & \multicolumn{3}{|c|}{ Bearden (Bc) @ Time (Min.) } \\
\hline & & & & $30 \mathrm{~B}_{\mathrm{C}}$ & $70 \mathrm{~B}_{\mathrm{C}}$ & $100 \mathrm{~B}_{\mathrm{c}}$ \\
\hline A & B & $\mathrm{C}$ & D & E & F & G \\
\hline MWS1 & 0.00 & 18.30 & 24.70 & 67 & 109 & 119 \\
\hline MWS2 & 0.52 & 18.00 & 24.10 & 63 & 106 & 116 \\
\hline MWS3 & 0.73 & 17.10 & 24.00 & 62 & 104 & 115 \\
\hline MWS4 & 3.80 & 16.40 & 22.50 & 58 & 99 & 109 \\
\hline MWS5 & 5.00 & 15.50 & 22.30 & 51 & 95 & 108 \\
\hline MWS6 & 5.20 & 15.20 & 21.80 & 50 & 90 & 107 \\
\hline MWS? & 5.53 & 15.10 & 21.30 & 49 & 89 & 106 \\
\hline MWS8 & 6.35 & 15.05 & 20.50 & 47 & 88 & 104 \\
\hline MWS9 & 6.82 & 15.00 & 20.10 & 46 & 86 & 101 \\
\hline
\end{tabular}


The influence of ferrous ion at different concentrations on the equivalent cement weight (ECW) is illustrated in Figure 7. These results were obtained from the pressurised mud balance; after each of the slurries were conditioned for about 30 minutes at $80^{\circ} \mathrm{F}$, and stirred with the cement mixer for 35 seconds at the speed of 12,000 rpm. The results in Figure 7 evidenced that, high concentration of ferrous ion in mix-water, resulted in the reduction of the cement slurry density.

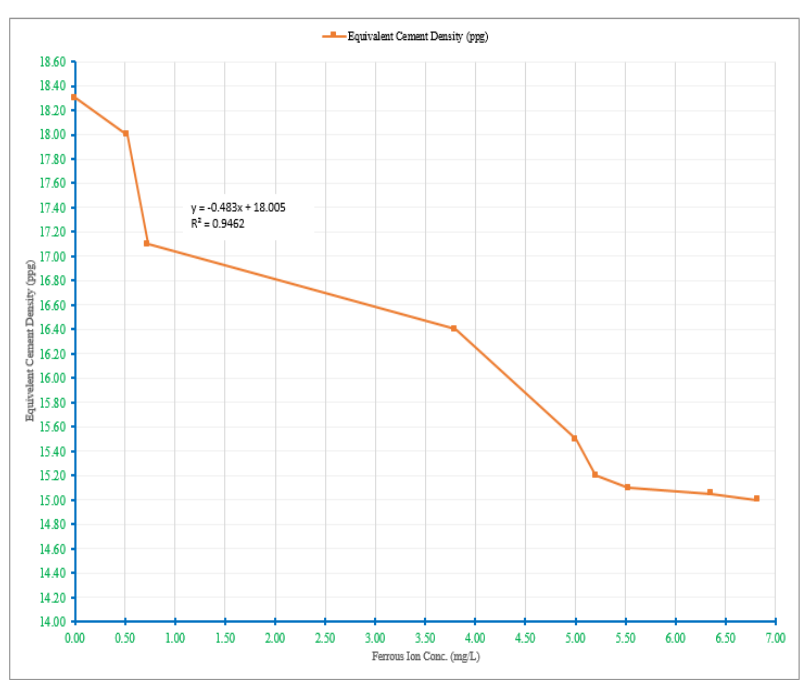

Figure 7: $\mathrm{Fe}^{2+}$ ion concentration as it influences the Equivalent Cement Weight $(\mathrm{ECW})$ after the formulation and conditioning of the ferrous cement slurry

In Figure 8, the figure shows that, the TT at the consistency of $30 \mathrm{~B}_{c}, 70 \mathrm{~B}_{\mathrm{c}}$, and $100 \mathrm{~B}_{\mathrm{c}}$, decreases at the rate of about $-2.51,-2.69$, and -1.86 minutes, respectively, whereas, synergistically, the ferrous ion concentration in mix-water increases at the rate $0.93 \mathrm{mg} / \mathrm{L}$, and the ferrous cement density decreases at the rate of $-0.48 \mathrm{ppg}$. Additionally, the model with the highest coefficient of determination, Rsquared $\left(R^{2}=0.9659\right)$ indicates that, the TT of ferrous cement slurry is better measured at $70 B_{c}$. These results were obtained when the experiments were conducted at the held condition, of simulated temperature of $250^{\circ} \mathrm{F}$, and pressure of 3,000 psi. It was also observed from these results that, at this simulated condition, the accelerating rates of the measured TT at $30 \mathrm{~B}_{\mathrm{c}}, 70 \mathrm{~B}_{\mathrm{c}}$, and $100 \mathrm{~B}_{\mathrm{c}}$ were the first fastest; when benchmarked with other investigated conditions.

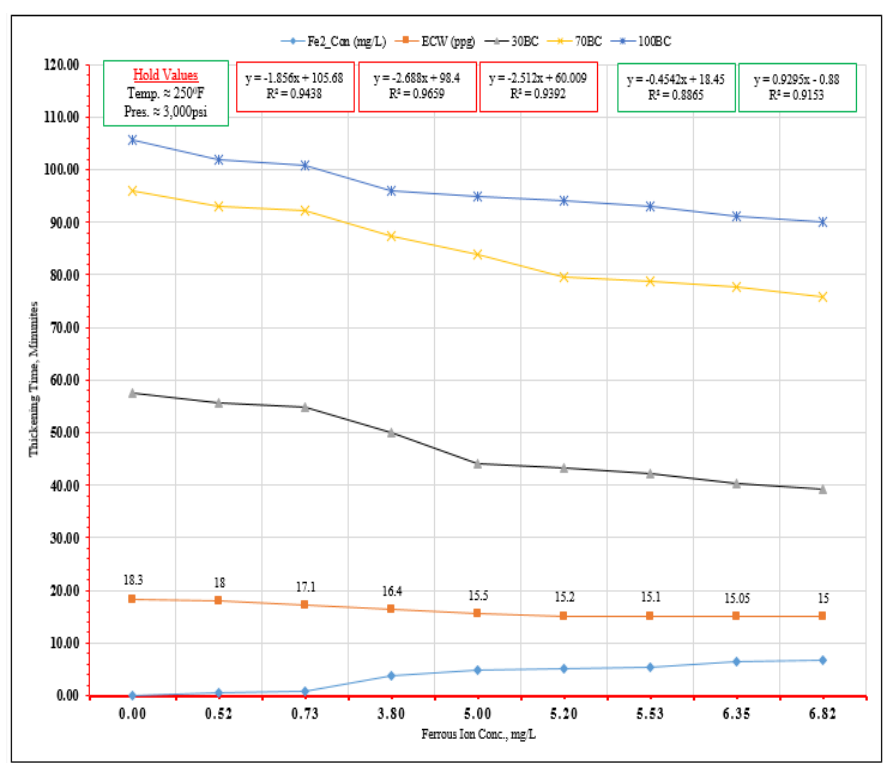

Figure 8: TT recorded at temperature $\left(250^{\circ} \mathrm{F}\right)$ and pressure $(3,000 \mathrm{psi})$.

Similarly, the results in Figure 9 took the same trend as those presented in Figure 8. The results of the TT experiments conducted under the experimental condition of temperature at $200^{\circ} \mathrm{F}$, and pressure at 3000 psi is presented in Figure 9. This results in Figure 9 illustrates that, TT at the consistency of 30 $\mathrm{B}_{c}, 70 \mathrm{~B}_{c}$, and $100 \mathrm{~B}_{c}$, respectively decreases at the rate of about $-2.71,-2.99$, and -2.07 minutes; 
whereas, as identically reported in Figure 8, likewise in Figure 9, the ferrous ion concentration in mixwater increases at the rate $0.93 \mathrm{mg} / \mathrm{L}$, and the ferrous cement density decreases at the rate of -0.48 ppg. Also, the model with the highest coefficient of determination, $\mathrm{R}$-squared $\left(\mathrm{R}^{2}=0.9554\right)$ specifies that, the TT of ferrous cement slurry is better measured at $70 \mathrm{~B}_{\mathrm{c}}$. It was also observed from these results that, at this simulated condition, the accelerating rates of the measured TT at $30 \mathrm{~B}_{c}, 70 \mathrm{~B}_{\mathrm{c}}$, and $100 \mathrm{~B}_{\mathrm{c}}$ were the third fastest; when equated with the results of the other experimental conditions.

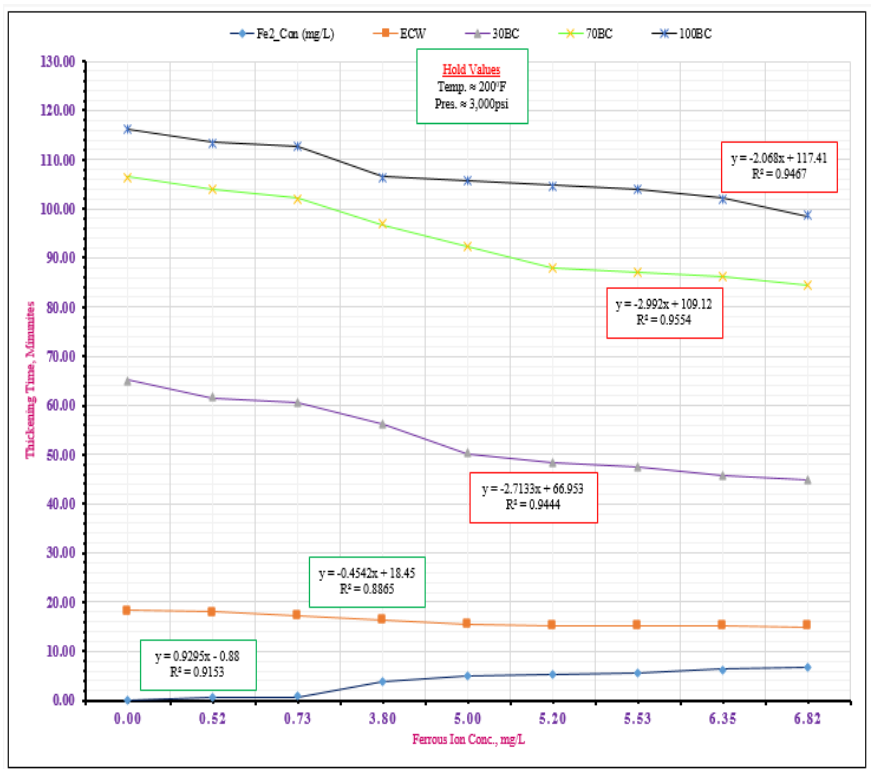

Figure 9:TT recorded at temperature and pressure of $200^{\circ} \mathrm{F}$, and 3,000 psi respectively.

Furthermore, the results in Figure 10 took the same trend as those presented in Figures 8 and 9. The results in Figure 10 illustrate the outcome of the TT investigated under the experimental condition of temperature at $250^{\circ} \mathrm{F}$, and pressure at $2500 \mathrm{psi}$, at the consistency of Bearden at $30 \mathrm{~B}_{\mathrm{c}}, 70 \mathrm{~B}_{\mathrm{c}}$, and 100 $B_{c}$. At these points, the TT was observed to decrease at the rate of about $-2.62,-2.82$, and -1.98 minutes; whereas, as reported in the previous results (Figures 8 to 9); also in Figure 10, the ferrous ion concentration in mix-water increases at the rate $0.93 \mathrm{mg} / \mathrm{L}$, and the ferrous cement density decreases at the rate of $-0.48 \mathrm{ppg}$. On the other hand, in this figure the model with the highest coefficient of determination, $\mathrm{R}$-squared $\left(\mathrm{R}^{2}=0.9554\right)$ specifies that, the TT of ferrous cement slurry is better measured at $70 \mathrm{~B}_{\mathrm{c}}$. It was also observed from these results that at this simulated condition, the accelerating rates of the measured TT at $30 \mathrm{~B}_{c}, 70 \mathrm{~B}_{c}$, and $100 \mathrm{~B}_{\mathrm{c}}$ were the second fastest; when compared with the results of the other experimental conditions.

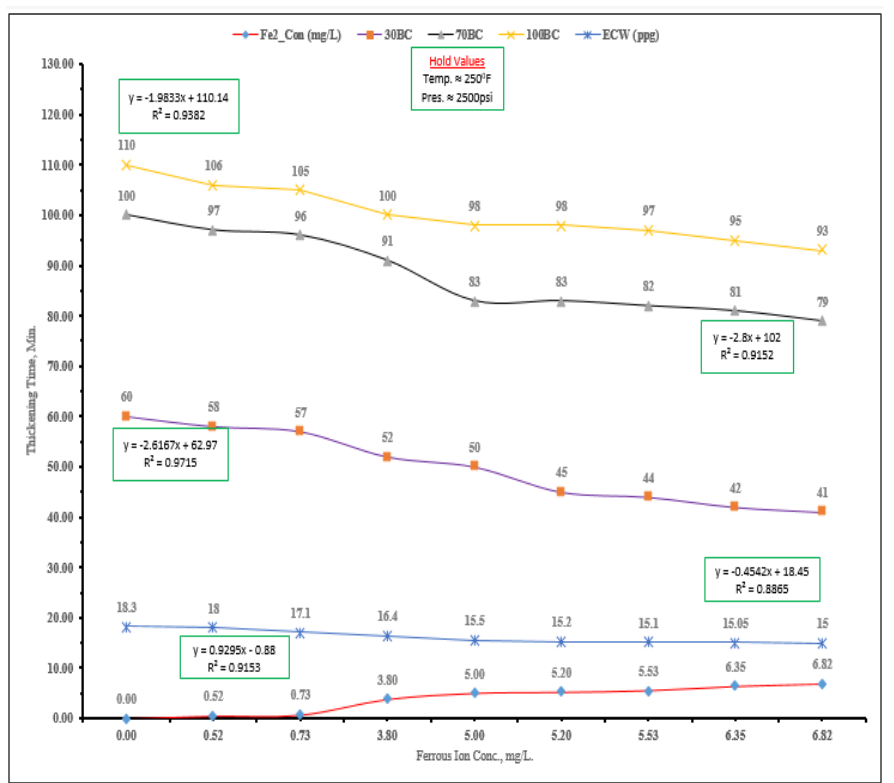

Figure 10: The TT results at temperature $\left(250^{\circ} \mathrm{F}\right)$; pressure $(2,500 \mathrm{psi})$. 
Still, the TT results in Figure 11 took the same decreasing trend, as those presented in Figures 8, 9 and 10. The results in this figure illustrates that, each of the TT at $30 \mathrm{~B}_{c}, 70 \mathrm{~B}_{\mathrm{c}}$, and $100 \mathrm{~B}_{\mathrm{c}}$, decreases at the rate approximated as $-2.78,-3.06$, and -2.12 minutes, respectively; whereas, as usual the ferrous ion concentration in mix-water increases at the rate $0.93 \mathrm{mg} / \mathrm{L}$, and the ferrous cement density decreases at the rate of $-0.48 \mathrm{ppg}$. Also, in this figure, the model with the highest coefficient of determination, $\mathrm{R}$-squared $\left(\mathrm{R}^{2}=0.955\right)$ agrees that, the $\mathrm{TT}$ of ferrous cement slurry is better measured at $70 \mathrm{~B}_{\mathrm{c}}$. It was also observed from these results that at this simulated condition, the accelerating rates of the measured TT at $30 \mathrm{~B}_{c}, 70 \mathrm{~B}_{c}$, and $100 \mathrm{~B}_{\mathrm{c}}$ were the least fast; when equated with the results of the other experimental conditions.

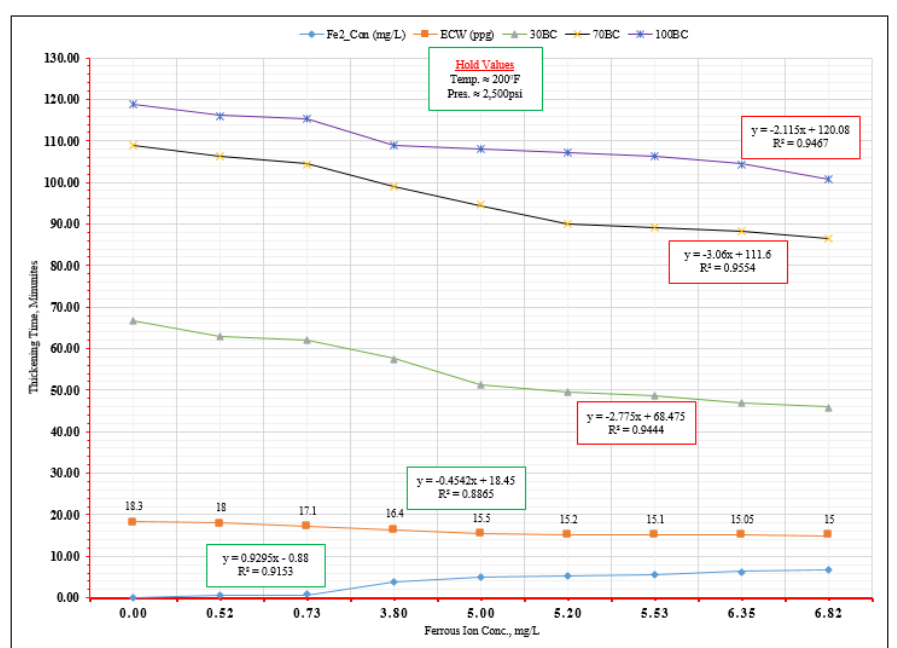

Figure 11: TT results at temperature $\left(200^{\circ} \mathrm{F}\right)$; pressure $(2,500 \mathrm{psi})$.

Generally, in terms of the simulated HPHT environments, the results explained that, when the same cement slurries were replicated, and exposed to a more hash HPHT environment, the TT of cement slurry accelerates more, and were best noticed at $70 \mathrm{~B}_{c}$, which conforms with the studies of Dargaud and Boukhelifa (2006); Broni-Bediako et al. (2015) that, $70 \mathrm{~B}_{\mathrm{c}}$ is considered, to indicate the maximum consistency for the slurry, to still be in a non-Newtonian pumpable state. Furthermore, the results have demonstrated that, high concentration of ferrous ion in the mix-water resulted in lower density of the cement slurry. The results also disclosed that, high concentration of ferrous ion in the mix-water resulted in accelerated TT. This characteristic is also exhibited by the accelerating additive called calcium chloride (Crook et al., 2006; Azar and Samuel, 2007). Also, this set-fast behaviour of high ferrous ion concentration towards cement slurry suggests that ferrous ion induces the exothermic reaction of $\mathrm{C}_{3} \mathrm{~A}$, and $\mathrm{C}_{3} \mathrm{~S}$ during cement hydration (Shahrudin et al., 1993; Bourgoyne et al., 1986). These premises as well, opines that mix-water with high concentration of ferrous ion are only suitable for cementing surface casings, and shallow oil-wells. Consequently, either high concentration of a retarder should be applied during the formulation of the ferrous cement slurry (Broni-Bediako et al., 2015), or the mix-water should be made potable (Yousuo et al., 2019), to prolong or retard the TT of the cement slurry for a deep HPHT oil-well. Therefore, this study's results conform to the findings of Bett (2010), which opined that, as the density of cement slurry decreases; the TT of the cement slurry accelerates. Furthermore, the collaborating synergistic effects of high pressure and high temperature on the ferrous cement slurry at high concentration resulted in accelerated TT. This also agrees with the study of Mofunlewi et al. (2019), which concluded that, at increasing high-pressure of any given high-temperature the TT of cement slurry accelerates. Though, this investigation did not consider the effects of ferrous ion concentration in mix-water towards TT. On the other hand, in this paper, despite some of the TT recorded at the consistency of $70 \mathrm{~B}_{\mathrm{c}}$ fell below the API required minimum TT of 90 minutes for Class G cement slurry (API Specification 10A, 1995), but accurate at $100 \mathrm{~B}_{c}$; the outcome of the models' $\mathrm{R}^{2}$ values discloses that, there is a strong linear relationship between the response surface of TT and the predictors of ferrous ion concentration, cement density, temperature, and pressure at the consistency of $70 \mathrm{~B}_{\mathrm{c}}$. The technicality of this, has been reported by many studies; although those studies did not include the impact of ferrous ion concentration in mix-water on TT (Dargaud and Boukhelifa, 2006; Broni-Bediako et al., 2015; Mofunlewi et al., 2019). 


\subsection{Conclusions}

This study concludes, that the weight-lightless exhibited by the ferrous cement slurry, is as a result of the continuous increase of ferrous ion concentration in mix-water, which was caused by the induced oxidation of $\mathrm{Fe}^{2+}$ into turbid. Also, the results demonstrated that, high concentration of ferrous ion in mix-water and the collaborating synergistic effect of high pressure and high temperature reduce or accelerate the thickening time of ferrous cement slurry, and also makes cement slurry, to set faster. Furthermore, this set-fast behaviour of high ferrous ion concentration towards cement slurry suggests that ferrous ion induces the exothermic reaction of $\mathrm{C}_{3} \mathrm{~A}$ during cement hydration. Finally, the overall results of the study opine that, mix-water with high concentration of ferrous ion are only suitable for cementing surface casings, and shallow oil-wells.

\section{Competing interest statement/ Funding statement}

The authors declared null and void, the existence of any conflict of interest. In addition, this research did not receive any form of grant or fund from funding agencies in the public, commercial, or not-forprofit sectors, just to mention but few.

\section{Acknowledgements}

For the provision of equipment, and the technical assistance given to actualise this paper, the authors sincerely thanked both the technologists of petroleum engineering, and chemistry laboratories of Niger Delta University, Nigeria.

\section{References}

Adesuyi, A. A. (2015). Environmental evaluation studies of Kolo Creek field facilities. 'Unpublished booklet'. Ph.D. Research Intern (EIA Team - Corporate Environment).

Alp, B. and Akin, S. (2013). Utilization of Supplementary Cementitious Materials in Geothermal Well Cementing, in Proceedings of Thirty-Eighth Workshop on Geothermal Reservoir Engineering, Stanford University, Stanford, California, pp. 1-7.

Amangabara, T. G. and Ejenma, E. (2012). Groundwater Quality Assessment of Yenagoa and Environs Bayelsa State, Nigeria between 2010 and 2011. Resources and Environment, 2(2), pp. 2029.

APHA (1998). Standard Methods for the Examination of Water and Wastewater, 20th edition, American public health association (APHA), AMWA, WWPCF, Washington, DC.

API Specification 10A (1995). Specification for Cements and Materials for Well Cementing, $22^{\text {nd }}$ Ed., American Petroleum Institute, Northwest Washington, DC.

Ashraf, M. A., Maah, M. J., and Yusoff, I. (2011). Heavy metals accumulation in plants growing in ex tin mining catchment, International Journal of Environmental Science and Technology, 8(2), pp. 401416.

Azar, J. J. and Samuel, G. R. (2007). Drilling Engineering, PennWell Corporation, Oklahoma.

Bett, E. K. (2010). Geothermal well cementing, materials and placement techniques. Geothermal Training Programme, United Nation University, Reports 2010 (10), pp. 99-130.

Boniface, A. O. and Appah, D. (2014). Analysis of Nigerian Local Cement for Slurry Design in Oil and Gas Well Cementation. Academic Research International, 5(4), pp. 176-181.

Bourgoyne Jr, A. T., Millheim, K. K., Chenevert, M. E., and Young Jr, F. S. (1986). Applied Drilling Engineering, SPE 2. Richardson, Texas: Society of Petroleum Engineers.

Bresson, B., Meducin, F., Zanni, H., and Noik, C. (2002). Hydration of tricalcium silicate $\left(\mathrm{C}_{3} \mathrm{~S}\right)$ at high temperature and high pressure. J. Mater. Sci. 37, pp. 5355-5365. 
Broni-Bediako, E., Joel, O. F. and Ofori-Sarpong, G. (2015). Evaluation of the performance of local cements with imported Class ' $G$ ' cement for oil well cementing operations in Ghana. Ghana Mining Journal, 15(1), pp. 78-84.

Creek, K. (2004). Shell Petroleum Development Company of Nigeria Limited. Available [online] at http://scholar.google.com/scholar_url?url=https $\% 3 \mathrm{~A} \% 2 \mathrm{~F} \% 2 \mathrm{Fs} 04$. staticshell.com\%2Fcontent $\% 2 \mathrm{Fdam}$ $\%$ 2Fshellnew\%2Flocal\%2Fcountry\%2Fnga\%2Fdownloads \%2Fpdf\%2Fkolocreekeiareport.pdf\&hl=e $\mathrm{n} \& \mathrm{sa}=\mathrm{T} \&$ oi=gga\&ct=a\&cd=1\&ei=GHDNWoSCC $83 \mathrm{kmAHlqqzoAg} \&$ scisig=AAGBfm $212 \mathrm{moCjMkE}$ uh79cfmyDSgTDQ52iA\&nossl=1\&ws=1366x657 [Accessed 11 April, 2018].

Crook, R. J., Benge, G., Faul, R. and Jones, R. R. (2006). Eight Steps to Ensure Successful Cement Jobs. Oil \& Gas Journal, pp. 16-17.

Dargaud, B. and Boukhelifa, L. (2006). Laboratory testing, evaluation, and analysis of well cements. pp.627-657 in E.B. Nelson and D. Guillot, editors, Well cementing, Second Edition, chapter B, Schlumberger, Sugar Land, Texas.

DeBruijn, G., Skeates, C., Greenaway, R., Harrison, D., Parris, M., et al. (2008). High-Pressure, High-Temperature Technologies Oilfield Review Available [online] at https://www.slb.com//media/files/oilfield-review/high-pressure-high-temperature [Accessed 26 March 2020].

Dillenbeck, L. (2010). The impact of cementing on proper well control. Available [online] http://www.google.com/url?sa=t\&rct=j\&q=\&esrc=s\&source=web\&cd=1\&cad=rja \&uact=8\&ved=2ah UKEwjzvZjpwcLcAhVDJMAKHXGQAqQQFjAAegQIARAC\&url=http\%3A\%2F\%2Fwww.iadc.or g\%2Fwp-content $\% 2$ Fuploads\%2FThe-impact-of-well_-cementing-on-proper-well control.pdf\&usg=AOvVaw3bGHLYa51AzDaIN5TZH9yg [Accessed 25 January 2018].

Ebuete, A. W. and Bariweni, P. A. (2019). Water Quality Index of Kolo Creek, Bayelsa State, Nigeria. J. Appl. Sci. Environ. Manage., 23(11), pp. 1923-1927.

Hole, H. M. (2008). Geothermal well cementing. Petroleum Engineering Summer School, Dubrovnik, workshop 26, pp.6.

Igbani, S. Ikporo, B. and Gbonhinbor R. J. (2018). Practical manual \& log book on petroleum engineering laboratory I (PEE 321). Kadmon Printing and Publishing Home, Yenagoa: Nigeria.

Igbani, S., Appah, D., and Ogoni, H. A. (2020). Effect of High Ferrous Ion Concentration in MixWater on the Compressive Strength Development of Oil-well Cement Sheath. International Journal of Engineering and Modern Technology, 6(2), pp. 33-51.

Kabinoff, K. B., Ekstrand, B. B., Shultz, S., Tilghman, S. E., and Fuller, D (1992). Determining accurate bottomhole circulating temperature for optimum cement slurrydesign. Society of Petroleum Engineers Western Regional Meeting, Bakersfield, California.

Kanesan, D., Suppiah, R. and Zubir, M. S. B. (2018). A study on the thickening time of Class F fly ash geopolymer cement for oil well cementing, ARPN Journal of Engineering and Applied Sciences, 2(13), pp. 682-685.

Khan, A. H., Rasul, S. B., Munir, A. K. M., Habibuddowla, M., Alauddin, M., Newaz, S.S. and Hussam, A. (2000). Appraisal of a simple arsenic removal method for groundwater of Bangladesh, $J$. Environ. Sci. Health, A35 (7), pp. 1021-1041.

Kiran, R., Teodoriu, C., Dadmohammadi, Y., Nygaard, R., Wood, D., et al. (2017). Identification and evaluation of well integrity and causes of failure of well integrity barriers (A review). Journal of Natural Gas Science and Engineering, 45, pp. 511-526.

Kutasov, I. M., and Kagan, M., (2002). Procedures to correct temperatures for deep offshore well. Oil and Gas Journal, 100(49), pp. 56-61. 
Mofunlewi, S. S., Joel, O., Appah, D., and Ubani, C. (2019). Synergistic effect of temperature and pressure on cement thickening time. International Journal of Engineering Trends and Technology. 67(4), pp. 59-63.

NSDWQ (2007). Nigeria Standard for Drinking Water Quality, Nigeria Industrial Standard, Approve by Standard Organization of Nigeria Governing Council. ICS 13. 060. 20: pp.15-19.

Madhusudana, R. B., Reddy, B. G., and Ramana, R. I. V. (2011). Effect of heavy mental present in mixing water on properties and sulfate attack on blended cement mortar. International Journal of Civil and Structural Engineering, 1(4), pp. 804-816.

Nygaard, R., Salehi, S., Weideman, B. and Lavoie, R. G. (2014). Effect of dynamic loading on wellbore leakage for wabamum area $\mathrm{CO}_{2}$-sequestration project. Journal of Canadian Petroleum Technology, 53(01), pp. 69-82.

Oyinkuro, A. O. and Rowland, D. E. (2017). Spatial Groundwater Quality Assessment by WQI and GIS in Ogbia LGA of Bayelsa State, Nigeria. Asian Journal of Physical and Chemical Sciences, 4(4), pp. $1-12$.

Patil, G. K., Jamkar, S. S., and Sadgir, P. A. (2011). Effects of Chemicals as Impurities in Mixing Water on Properties of Concrete. International Journal of Research in Chemistry and Environment, 1(1), pp. 35-41.

Pattinasarany, A. and Irawan, S. (2012). The Novel Method to Estimate Effect of Cement Slurry Consistency toward Friction Pressure in Oil/Gas Well Cementing. Res. J. Appl. Sci. Eng. Technol., 4 (22), pp. 4596-4606.

Purvis, D. L., Mueller, D. T. Dawson J. C. and Bray, W. S. (1993). Thickening time test apparatus provides method of simulating actual shear history of oil well cements. in Proceedings of SPE Annual Technical Conference and Exhibition Houston, Society of Petroleum Engineers, Texas, pp. 647-660.

Roshan, H. and Asef, M. R. (2010). Characteristics of Oil Well Cement Slurry Using CMC, Journal of Society of Petroleum Engineers Drilling and Completion, SPE 11446, 25(3), pp. 328-335.

Salam, K. K., Arinkoola, A. O., Ajagbe, B. and Sanni, O. (2013). Evaluation of Thickening Time of Oil Field Class G Cement Slurry at High Temperature and Pressure using Experimental Design. International Journal of Engineering Sciences, 2(8), pp. 361 - 367.

Saleh, F. K., Rivera, R., Saleh, S. and Teodoriu, C. (2018). How Does Mixing Water Quality Affect Cement Properties, In SPE International Conference and Exhibition on Damage Control held in Lafayette, Louisiana, USA, 7-9 February, 2018, SPE-189505-MS, pp. 1-10.

Shahrudin, S., Samsuri, A., Suhiami, A., Nasir, A. S., and Ahmad, Z. (1993). Possibility Studies of Using Local Cement in Oil and Gas Well Cementing Operations in Malaysia. [Online] available from <http://eprints.utm.my/4029/1/SKMBT_60007062016310.pdf. [Accessed 27 February 2018].

Soltanian, H. and Mortazavi, A. R. (2016). The Use of Nanoaccelerator in Cement Slurries in Low Temperature Well Conditions. Journal of Petroleum Science and Technology, 6(1), pp. 109-114.

Valic, M. and Stepisnik, J. (1998). A study of hydration of cement pastes by reflection of ultrasonic shear waves, Part I: apparatus, experimental method and application examples. Kovine, Zlitine, Tehnologije, 32(6), pp. 551-560.

Van Kleef, R. P. A. R. and Van Vliet, J. P. M. (1993). Improving the reliability of cement-setting-time tests by taking into account the influence of shear. SPE Drill. Complet., 8(1), pp. 51-56.

WHO (2011). Guidelines for Drinking-Water Quality, 4th edition, World Health Organization (WHO) Press, Geneva, Switzerland. 
World Industrial Information (2016). Kolo Creek Oil Field, Available [Online] at https://www.industryabout.com/country-territories-3/1888-nigeria/oil-and-gas/39953-kolo-creek-oilfield [Accessed 11 April, 2018].

Yousuo, D., Igbani, S., and Raphael, T. S. (2019). Design of a Portable Tubular Filter Pipe for Borehole Water Purification Systems, Journal of Physical Science and Innovation, 11(3), pp. 18-47.

Zacchaeus, O. O., Adeyemi, B. M., Adedeji, A. A., Adegoke, A. K., Anumah, O. A. et al. (2020). Effects of industrialization on groundwater quality in Shagamu and Ota industrial areas of Ogun state, Nigeria, Heliyon, 6, pp.1-13. Available [online] at https://doi.org/10.1016/j.heliyon.2020.e04353 [Accessed 12 September 2020].

Zhang, J., Weissinger, E. A., Peethamparan, S. and Scherer, G. W. (2010). Early hydration and setting of oil well cement. Cement and Concrete Research, 40, pp. 1023-1033.

\section{Cite this article as:}

Igbani S., Ogoni H. A. and Appah D., 2020. The Thickening Time of Ferrous Cement Slurry System in High-Pressure and High-Temperature Environment. Nigerian Journal of Environmental Sciences and Technology, 4(2), pp. 351-369. https://doi.org/10.36263/nijest.2020.02.0219 